\title{
DO CHANGING DIAGNOSTIC CRITERIA FOR GESTATIONAL DIABETES INFLUENCE PREGNANCY OUTCOME?
}

\author{
Ivka Djaković ${ }^{1}$, Senka Sabolović Rudman ${ }^{1}, V_{\text {esna Gall }}{ }^{1}$, Andro Košec ${ }^{2}$, \\ Marina Markuš Sandrić ${ }^{3}$ and Vesna Košec ${ }^{1}$
}

${ }^{1}$ University Department of Gynecology and Obstetrics, ${ }^{2}$ University Department of ENT and Head and Neck Surgery, Sestre milosrdnice University Hospital Center;

${ }^{3}$ National Center for External Evaluation of Education, Zagreb, Croatia

\begin{abstract}
SUMMARY - The incidence of pregnancy related diabetes has been steadily increasing during the past decade. The aim of this retrospective study was to evaluate the type and prevalence of gestational diabetes complications after implementing new diagnostic criteria for gestational diabetes. The incidence of gestational diabetes, maternal age, mode of delivery and birth weight were analyzed. Study patients were divided into three groups. The first group consisted of patients who gave birth during 2005, the second group during 2011 and the third group during 2012. In 2005, the World Health Organization criteria were used on diagnosing gestational diabetes, whereas in 2011 and 2012 the criteria issued by the International Association of Diabetes and Pregnancy Study Groups were considered. There was no statistically significant difference among the groups according to maternal age, birth weight $(\mathrm{p}=0.203)$ and mode of delivery $(\mathrm{p}=0.883)$. Cesarean section was performed in about $30 \%$ of deliveries in all groups combined. There was no significant difference in the number of neonatal hypertrophy ( $\mathrm{p}=0.348$ ), although the distribution of hypertrophy showed a tendency towards higher values in 2005. The incidence of gestational diabetes was $2.2 \%$ in 2005, 6.6\% in 2011 and $12 \%$ in 2012. In conclusion, difference in the incidence of pregnancy related diabetes appeared to have resulted directly from using different diagnostic criteria. The new criteria contributed to a relatively higher incidence of gestational diabetes but also achieved better gestational glycemic control and consequently better fetal growth regulation.
\end{abstract}

Key words: Diabetes, gestational - diagnosis; Fetal growth

\section{Introduction}

Diabetes mellitus type 2 is nowadays a widespread condition in the general population with potentially numerous complications. New diagnostic criteria may influence the incidence and possibly outcomes as well. Undertreated gestational diabetes can lead to various complications of pregnancy, labor and perinatal out-

Correspondence to: Ivka Djakovic, MD, University Department of Gynecology and Obstetrics, Sestre milosrdnice University Hospital Center, Vinogradska c. 29, HR-10000 Zagreb, Croatia

E-mail: ivkadj@yahoo.com

Received August 14, 2015, accepted February 11, 2016 come with long lasting repercussions. Gestational diabetes is diabetes first diagnosed during pregnancy. The definition includes previously unrecognized diabetes and impaired glucose tolerance ${ }^{1,2}$. Obesity and disturbances of carbohydrate metabolism are the main reasons for the increased incidence of gestational diabetes.

Diagnostic criteria for gestational diabetes vary widely. Until 2010, the most often used criteria were the World Health Organization (WHO) guidelines including oral glucose tolerance test (OGTT) from capillary blood glucose $6.1 \mathrm{mmol} / \mathrm{L}$ and $7.8 \mathrm{mmol} / \mathrm{L}$ after 2 hours, measured during the third trimester after ultrasonic proof of fetal hypertrophy, polyhydramnion or 
placental changes ${ }^{3}$. This enabled detection of gestational diabetes mostly during the second half of pregnancy, and the need for earlier diagnosis was recognized. Changing the criteria should have especially been focused on ensuring early diagnosis and proper management before the onset of gestational diabetes complications.

The International Association of Diabetes and Pregnancy Study Groups (IADPSG) has assembled guidelines that can be used as refined diagnostic criteria and has classified gestational diabetes based on the Hyperglycemia and Adverse Pregnancy Outcome study (HAPO study) that recommends diagnosing gestational diabetes based on venous plasma glucose values ${ }^{4}$. The results indicate the diagnosis when fasting venous plasma glucose up to 20 weeks of pregnancy is $\geq 5.1 \mathrm{mmol} / \mathrm{L}$. This should be supported with the OGTT; when done at 24-32 weeks of gestation, fasting venous plasma glucose should be $\geq 5.1 \mathrm{mmol} / \mathrm{L}$, followed by $\geq 10.0 \mathrm{mmol} / \mathrm{L}$ after 1 hour and finally $\geq 8.5 \mathrm{mmol} / \mathrm{L} 2$ hours after glucose intake. If one or more of these values are equal or higher after $75-\mathrm{g}$ OGTT, the diagnosis of gestational diabetes should be established. Overt diabetes can be diagnosed when fasting plasma glucose is $\geq 7.0 \mathrm{mmol} / \mathrm{L}, \mathrm{HbA} 1 \mathrm{c}$ level $\geq 6.5 \%$ or random plasma glucose over $11.1 \mathrm{mmol} / \mathrm{L}^{5}$.

The aim of this retrospective study was to evaluate the type and incidence of gestational diabetes complications after implementation of the new diagnostic criteria for gestational diabetes at the Department of Obstetrics, Sestre milosrdnice University Hospital Center in Zagreb, Croatia.

\section{Patients and Methods}

Data from the maternity ward were retrospectively collected. The age of diabetic mothers, body mass index (BMI), gestational weight gain, mode of delivery and birth weight recorded in 2005 were compared with those recorded in 2011 and 2012. In 2005, the WHO criteria were used for detection of gestational diabetes, whereas in 2011 and 2012 the HAPO study guidelines were implemented. Statistical analyses were performed by the SPSS version 13.0 (SPSS, Chicago, IL, USA) using Student's t-test and $\chi^{2}$-test.

\section{Results}

Total number of deliveries in 2005 was 2359, of which $52(2.2 \%)$ women were diagnosed with gesta-

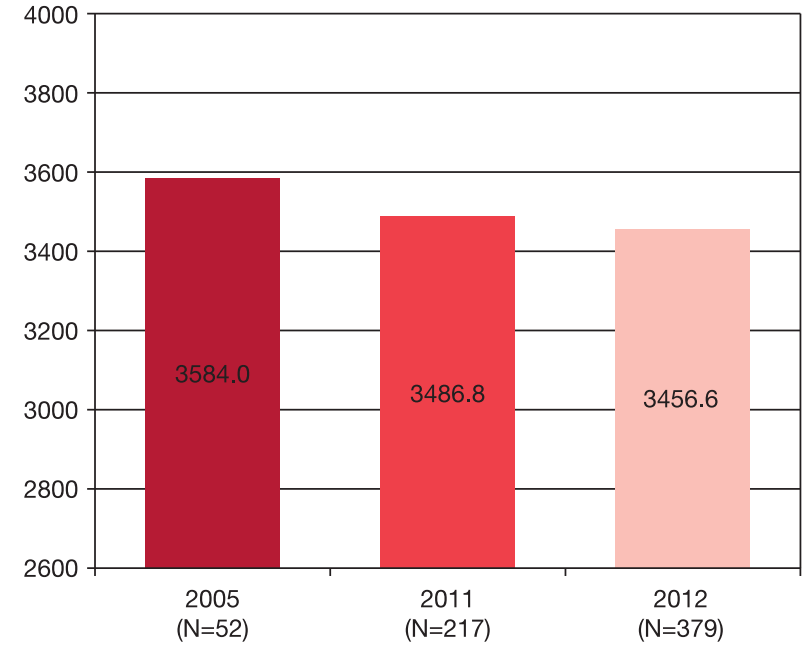

Fig. 1. Mean birth weight.

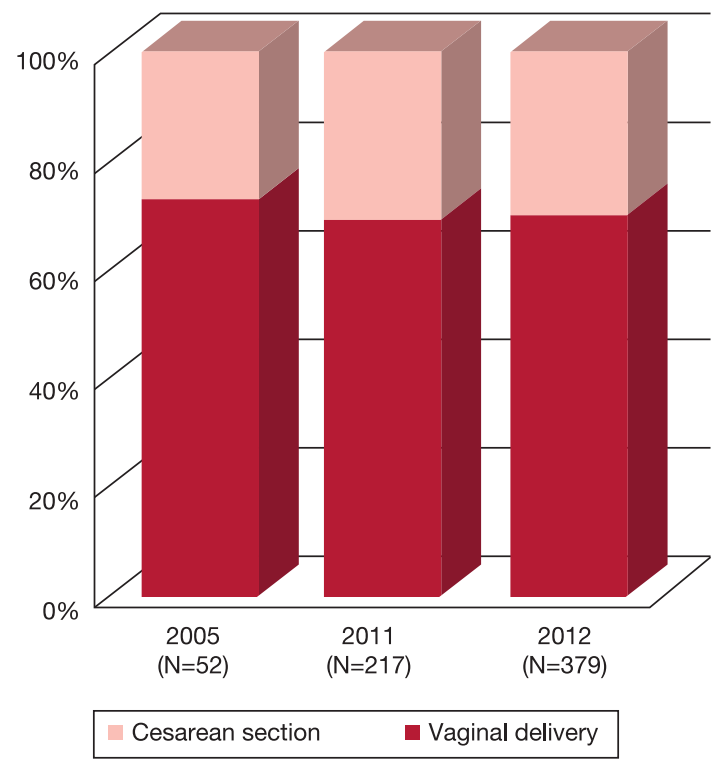

Fig. 2. Mode of delivery (\%).

tional diabetes. In 2011, total number of deliveries was 3250 with a $6.6 \%$ incidence of gestational diabetes $(\mathrm{n}=214)$. In 2012, 3157 women delivered in our Hospital and the number of patients with gestational diabetes increased to $12 \%(n=379)$. The mean age of patients from all three groups was $31 \pm 4.3$ years. Median BMI in all groups was the same, i.e. 22 before pregnancy and 27 upon admission to the hospital for delivery. However, median weight gain during pregnancy in 2011 and 2012 was $12 \mathrm{~kg}$ as compared with $14 \mathrm{~kg}$ in 2005. The mean maternal body weight at the beginning of pregnancy was $61 \mathrm{~kg}$. 


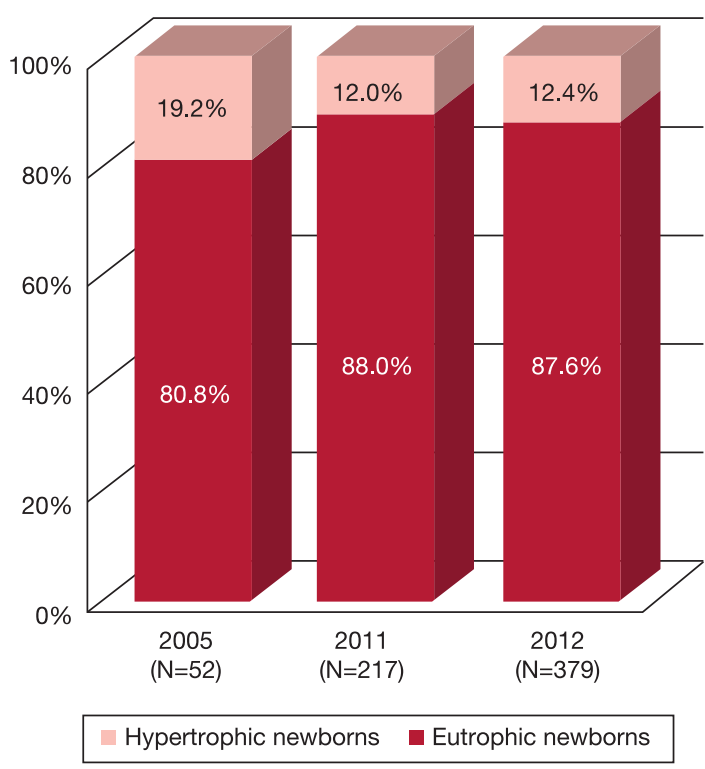

Fig. 3. Hypertrophic newborns (\%).

The mean neonatal birth weight in the group with gestational diabetes was $3584 \mathrm{~g}$ in 2005, $3487 \mathrm{~g}$ in 2011 and $3457 \mathrm{~g}$ in 2012 (Fig. 1). Analysis of variance yielded no significant between-group difference $(\mathrm{F}=1.601 ; \mathrm{df}=2 ; \mathrm{p}=0.203)$.

Cesarean section was the mode of delivery in $26.9 \%$ of deliveries in 2005, 30.4\% in 2011 and $29.6 \%$ in 2012 (Fig. 2), with no significant between-group difference $\left(\chi^{2}=0.248 ; \mathrm{df}=2 ; \mathrm{p}=0.883\right)$.
Ten (19.2\%), $26(12.0 \%)$ and 47 (12.4\% patients with gestational diabetes gave birth to hypertrophic newborns in 2005, 2011 and 2012, respectively. There was no between-group difference in birth weight $\left(\chi^{2}=\right.$ 2.110; $\mathrm{df}=2 ; \mathrm{p}=0.348$ ) (Fig. 3).

In 2005, there were $7.7 \%$ of newborns weighing $4250 \mathrm{~g}$ or more, in 2011 their percentage decreased to $4.2 \%$, and in 2012 it was $4.5 \%$. The $3750-4249 \mathrm{~g}$ weight group accounted for $36.5 \%$ of newborns in $2005,24 \%$ in 2011 and $21.1 \%$ in 2012 . There was a significant difference between the 2005 and 2011 groups, as well as between 2005 and 2012 groups ( $\mathrm{p}<0.05$ both).

Indications for cesarean section in 2005, 2011 and 2012 are shown in Figure 4. Due to the sample characteristics, no statistical test other than descriptive statistics could be employed for this parameter.

\section{Discussion}

The growing incidence of obesity and carbohydrate metabolic disorders poses a major problem in pregnant women with gestational diabetes ${ }^{6}$. Repercussions of gestational diabetes include fetal macrosomia, birth trauma to both mother and newborn, the need of labor induction or cesarean section, transient neonatal morbidity, neonatal hypoglycemia, perinatal death, obesity and/or diabetes developing later in the newborn's life.

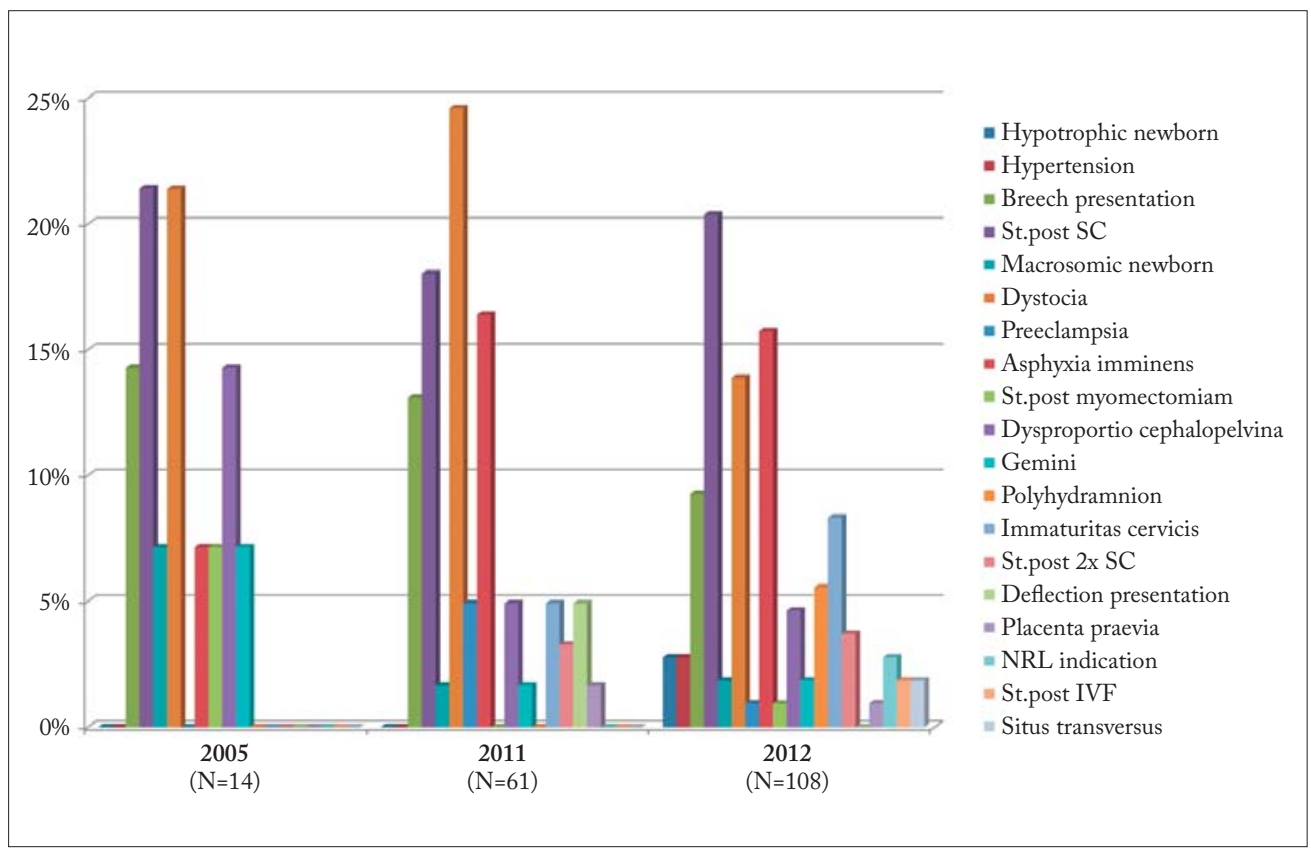

Fig. 4. Indications

for cesarean section. 
The incidence varies among ethnic groups, increases with obesity, maternal age and known genetic predisposition $^{7,8}$. The criteria for diagnosing diabetes in pregnant women are different from those in general population. In the beginning of pregnancy, increasing hormone levels exert combined proinsulin and anabolic actions, while later during pregnancy, diabetogenic hormones influence glucose utilization, especially in third trimester, and increase insulin utilization by more than fourfold. If there is already weakness of pancreatic beta cell islets of Langerhans, different degrees of glucose intolerance will manifest ${ }^{3,9}$. There are no uniform criteria for the diagnosis of gestational diabetes. O'Sullivan's OGTT criteria, the National Diabetes Data Group (NDDG) criteria and WHO criteria can be used for successful detection of a portion of pregnant women with diabetes ${ }^{3}$. The HAPO study was launched to explain the observed clinical trend of poor outcomes in pregnancies with different grades of glucose intolerance. Conclusions of the HAPO study stated that the incidence of high birth weight, C-peptide levels in the umbilical cord, or the percentage of fat in the body weight of a fetus greater than 90 percentile was twofold greater if glucose value was equal to or higher than the limit value. The incidence of preeclampsia was twice higher if one or more glucose values were equal to or higher than the limit values and the incidence of premature births and primary cesarean sections was higher than $45 \%$. Since 2011, the IADPSG criteria are in use in our Department. These guidelines contribute to better risk group identification and stratification, but also change the method and extent of monitoring a large number of pregnant women ${ }^{10-12}$.

In our Department, the incidence of gestational diabetes was $2.2 \%$ in $2005,6.6 \%$ in 2011 and $12.0 \%$ in 2012. In the HAPO study, the overall percentage of pregnant women with gestational diabetes was $17.8 \%$. Due to the changed criteria for gestational diabetes, in 2005 we had only $2.2 \%$ of patients with gestational diabetes in comparison with 2011 and 2012 when the new and stricter criteria were applied. The difference in the incidence between 2011 and 2012 can be explained by further adjusting the implementation of the new criteria. A large Chinese study compared the incidence and outcome of pregnancy under NDDG and IADPSG criteria. The prevalence of gestational diabetes when using IADPSG criteria was $18.9 \%$. The prev- alence of cesarean section, macrosomia, hypoglycemia, neonatal and perinatal death was significantly lower when the IADPSG criteria were used ${ }^{13}$. The rate of cesarean sections in the group with IADPSG criteria was $46 \%$ and was significantly lower than in the group with NDDG criteria. In our study population, the mean weight at the beginning of pregnancy was $61 \mathrm{~kg}$ in all groups, while at the end of pregnancy it was 74 $\mathrm{kg}$ in 2005 and $72 \mathrm{~kg}$ in 2011 and 2012. We found no statistically significant difference in the maternal mean weight or BMI among the three groups, but there was a slight decrease of gestational weight gain in 2011 and 2012. These data may indicate better dietary control and therefore lower weight gain in the 2011 and 2012 groups. In our study, cesarean section was performed in $30 \%$ of patients regardless of the criteria applied. The median weight of neonates did not differ significantly between the 2011 and 2012 groups, yet showing a decreasing tendency, but we found significant difference in the $3750-4249$ g group $(\mathrm{p}<0.05)$ between 2005 and 2011, as well as between 2005 and 2012. Although there was no significant difference in the number of macrosomic children between these groups, we also observed a decreasing tendency in 2011 and 2012 as compared with 2005. These results indicate better glycemic control in mothers and therefore a decreased number of hypertrophic children in 2011 and 2012.

The percentage of macrosomic children in the Chinese study and our study using IADPSG criteria was similar $(6.3 \%$ and $7.6 \%$, respectively). The increase in the number of pregnant women with gestational diabetes is an additional financial burden on the healthcare system but it brings long-term savings by preventing morbidity both during pregnancy and in the child's later life ${ }^{14,15}$. Newborns of mothers with gestational diabetes have a higher risk of developing psychomotor disorders and schizophrenia. This alone should encourage monitoring and treating even mild hyperglycemia in pregnancy, as evidenced by the ACHOIS and MFMU studies ${ }^{16,17}$. The high prevalence of gestational diabetes can be explained by the worldwide epidemic of obesity, prediabetes and diabetes ${ }^{18}$.

Although we have tried to utilize uniform criteria for timely and accurate diagnosis and monitoring of pregnant women with gestational diabetes, it seems that the process will not always go as anticipated due to many resistances to introducing new criteria. Al- 
though the results of HAPO study clearly show a lower incidence of macrosomic children, preeclampsia, preterm delivery, shoulder dystocia and birth injuries, the methodology and results of the HAPO study are under constant criticism ${ }^{19}$. The US National Institute of Health has not accepted the IADPSG recommendations, deeming the consequent prevalence of gestational diabetes too high and without objective justification. They are actively working on the adoption and refining their own guidelines ${ }^{20,21}$. It should be noted that no clinical study showed negative effect of utilizing the IADPSG based treatment of gestational diabetes. On the contrary, the results of the HAPO study clearly put the fetus in the center of interest in pregnant women with gestational diabetes and stress the importance of observing the fetus as a patient. The importance of maintaining an optimal intrauterine environment is not only a prerequisite for good perinatal outcome, but also provides conditions that encourage full development of fetal potential and minimize late effects of gestational diabetes. It is known that children from unregulated pregnancies with gestational diabetes often develop obesity, metabolic syndrome and have difficulties with social intercourse. This concept of fetal programming has been studied widely in clinical, epidemiological and animal studies ${ }^{22,23}$.

During the few months of pregnancy, the diagnosis and treatment of gestational diabetes do not endanger the health and life of pregnant women, but it might be an additional motivation to adopt healthy habits and a quality lifestyle after pregnancy. This is the best way to prevent the development of diabetes type 2 , to which many of the healthy and especially gestational diabetes women are predisposed to develop later in life.

\section{Conclusion}

In our study, no significant differences in birth weight and mode of delivery were found in patients with gestational diabetes according to the two different diagnostic criteria. There was, however, a significant difference in the distribution of higher birth weight, showing the use of the IADPSG criteria to be associated with lower neonatal weight values in patients with gestational diabetes. The incidence trends similar to the HAPO study results can be expected in the future. In 2011 and 2012, better maternal glycemic control and therefore a decreased number of hypertro- phic children were recorded. We found no statistically significant difference in the maternal mean weight and BMI among the three groups, but there was a slight decrease of gestational weight gain in 2011 and 2012. These data may indicate better dietary control and therefore lower weight gain in the 2011 and 2012 groups. Although these new diagnostic criteria have not been widely accepted, our results showed benefits for both the mother and the baby.

\section{References}

1. Đelmiš J. Dijabetes i trudnoća. In: Kuvačić I, Kurjak A, Đelmiš J, editors. Porodništvo. Zagreb: Medicinska naklada; 2009. p. 365-73. (in Croatian)

2. American Diabetes Association. Diagnosis and classification of diabetes mellitus. Diabetes Care. 2014;37 Suppl 1:S81-90. http://dx.doi.org/10.2337/dc14-S081

3. Đelmiš J, Ivanišević M, Juras J, Herman M. Diagnosis of hyperglycemia in pregnancy. Gyneacol Perinatol. 2010;19(2): 86-9.

4. International Association of Diabetes and Pregnancy Study Groups. International Association of Diabetes and Pregnancy Study Groups Recommendations on the Diagnosis and Classification of Hyperglycemia in Pregnancy. Diabetes Care. 2010; 33:676-82. http://dx.doi.org/10.2337/dc09-1848

5. HAPO Study Cooperative Research Group; Metzger BE, Lowe LP, Dyer AR, Trimble ER, Chaovarindr U, et al. Hyperglycemia and adverse pregnancy outcomes. N Engl J Med. 2008;358(19):1991-2002. http://dx.doi.org/10.1056/NEJMoa 0707943

6. Harder T, Franke K, Kohlhoff R, Plagemann A. Maternal and paternal family history of diabetes in women with gestational diabetes or insulin-dependent diabetes mellitus type I. Gyneacol Obstet Invest. 2001;51(3):160-4. http://dx.doi.org/52916

7. King H. Epidemiology of glucose intolerance and gestational diabetes in women of childbearing age. Diabetes Care. 1998; (21Suppl 2):B9-13.

8. Berkowitz GS, Lapinski RH, Wein R, Lee D. Race/ethnicity and other risk factors for gestational diabetes. Am J Epidemiol. 1992;135:965-73

9. Kuhl C. Etiology and pathogenesis of gestational diabetes. Diabetes Care. 1998;21(Suppl 2):B19-26.

10. Flack JR, Ross GP, Ho S, McElduff A. Recommended changes to diagnostic criteria for gestational diabetes: impact on workload. Aust N Z J Obstet Gyneacol. 2010;50(5):439-43. http:// dx.doi.org/10.1111/j.1479-828X.2010.01218.x

11. Coustan DR, Lowe LP. Metzger BE. The Hyperglycemia and Adverse Pregnancy Outcome (HAPO) study: can we use the results as a basis for change? J Matern Fetal Neonatal 
Med. 2010;23(3):204-9. http://dx.doi.org/10.3109/14767050 903550667

12. Kautzky-Willer A, Bancher-Todesca D, Pollak A, Repa A, Lechleitner M, Weitgasser R. Gestational diabetes mellitus. Wien Klin Wochenschr. 2012;(124 Suppl 2):58-65. (in German) http://dx.doi.org/10.1007/s00508-012-0265-3

13. Wei Y, Yang H, Zhu W, Yang H, Li H, Yan J, et al. International Association of Diabetes and Pregnancy Study Group criteria are suitable for gestational diabetes mellitus diagnosis: further evidence from China. Chin Med J (Engl). 2014;127 (20):3553-6.

14. Coustan DR. Diagnosis of gestational diabetes. Scand J Clin Lab Invest Suppl. 2014;244:27-33. http://dx.doi.org/10.3109/ 00365513.2014 .936677$.

15. Towpik I, Wender-Ozegowska E. Is diabetes mellitus worth treating? Ginekol Pol. 2014;85(3):220-5. (in Polish)

16. Moss JR, Crowther CA, Hiller JE, Willson KJ, Robinson JS. Costs and consequences of treatment for mild gestational diabetes mellitus - evaluation from the ACHOIS randomised trial. BMC Pregnancy Childbirth. 2007;7:27. http://dx.doi. org/10.1186/1471-2393-7-27.

17. Landon MB. The NICHD Maternal and Fetal Medicine Unit (MFMU) Network Gestational Diabetes Mellitus Trial: can we use the results as the basis for changing current screening approaches? J Matern Fetal Neonatal Med. 2010;23(3):210-3. http://dx.doi.org/10.3109/14767050903550683.

18. Correa PJ, Vargas JF, Sen S, Illanes SE. Prediction of gestational diabetes early in pregnancy: targeting the long-term complications. Gynecol Obstet Invest. 2014;77(3):145-9. http: //dx.doi.org/10.1159/000357616

19. Cundy T. Proposed new diagnostic criteria for gestational diabetes - a pause for thought? Diabet Med. 2012;29(2):176-80. http://dx.doi.org/10.1111/j.1464-5491.2011.03407.x.

20. Cosson E, Valensi P, Carbillon L. Screening for dysglycaemia during pregnancy: proposals conciliating International Association of Diabetes and Pregnancy Study Group (IADPSG) and US National Institutes of Health (NIH) panels. Diabetes Metab. 2015;41(3):239-43. http://dx.doi.org/10.1016/j.diabet.2014.08.001.

21. Petrovic O. How should we screen for gestational diabetes? Curr Opin Obstet Gynecol. 2014;26(2):54-60. http://dx.doi. org/10.1097/GCO.0000000000000049.

22. Finer S. Fetal programming via maternal diabetes: the controversy continues. Diabet Med. 2015;32(3):291-4. http://dx.doi. org/10.1111/dme.12675.

23. Jeve YB, Konje JC, Doshani A. Placental dysfunction in obese women and antenatal surveillance strategies. Best Pract Res Clin Obstet Gynaecol. 2015;29(3):350-64. http://dx.doi.org/ 10.1016/j.bpobgyn.2014.09.007.

Sažetak

\section{UTJEČU LI NOVI DIJAGNOSTIČKI KRITERIJI ZA GESTACIJSKI DIJABETES NA ISHOD TRUDNOĆA?}

\section{Djakovic, S. Sabolović Rudman, V. Gall, A. Košec, M. Markuš Sandrić i V. Košec}

Incidencija gestacijskog dijabetesa je u stalnom porastu u proteklom desetljeću. Cilj ove retrospektivne studije bio je utvrditi komplikacije gestacijskog dijabetesa $\mathrm{i}$ ishode trudnoća nakon promjene kriterija za dijagnozu gestacijskog dijebetesa. Analizirana je incidencija dijabetesa u trudnoći, dob majki, način dovršenja porođaja i težina novorođenčadi. Ispitanice su bile podijeljene u tri skupine. U prvoj skupini su bile žene koje su rodile u 2005. godini, u drugoj skupini one koje su rodile 2011. godine, a u trećoj skupini one koje su rodile 2012. godine. Za dijagnozu gestacijskog dijabetesa 2005. godine korišteni su kriteriji Svjetske zdravstvene organizacije, a 2011. i 2012. godine kriteriji IADPSG (International Association of Diabetes and Pregnancy Study Groups). U ispitivanim skupinama nije nađena statistički značajna razlika s obzirom na dob rodilja. Nije bilo statistički značajne razlike u prosječnoj težini novorođenčadi $(p=0,203)$ među ispitivanim skupinama. Također nije nađena statistički značajna razlika niti u načinu dovršenja porođaja $(\mathrm{p}=0,883)$. U ispitivanom uzorku carskim rezom rodilo je oko $30 \%$ trudnica. Nije bilo statistički značajne razlike u pojavnosti fetalne hipertrofije ( $\mathrm{p}=0,348)$, ali je 2005. godine rođeno više djece u skupinama s većom porođajnom masom. Godine 2005. incidencija gestacijskog dijabetesa bila je 2,2\%, 2011. godine 6,6\%, a 2012. godine 12\%. Razlika u incidenciji gestacijskog dijabetesa posljedica je primjene različitih dijagnostičkih kriterija. Novi kriteriji su doprinijeli porastu incidencije gestacijskog dijabetesa, ali i boljoj regulaciji glikemije te posljedično boljoj regulaciji fetalnoga rasta.

Ključne riječi: Dijabetes, gestacijski-dijagnostika; Fetusni rast 